УДК 340.132.6

DOI https://doi.org/10.32837/pyuv.v1i4(29).386

\author{
В. К. Антошкіна \\ orcid.org/0000-0003-2136-3073 \\ кандидат юридичних наук, доцент, \\ доцент кафедри галузевих юридичних дисииллін \\ Бердянського університету менедженту і бізнесу
}

\title{
СПОСОБИ І ПРАВИЛА ТЛУМАЧЕННЯ НОРМ ПРАВА ТА ДОГОВОРІВ
}

Необхідність тлумачення викликана багатьма факторами як об'єктивного, так і суб'єктивного характеру. При цьому можна стверджувати, що необхідність тлумачення зумовлена не тільки i не стільки технічною недосконалістю зовнішньої форми частини правових норм (їх незрозумілістю, неоднозначністю), а випливає із суті правореалізації, оскільки в самій природі правової норми закладена необхідність ії інтерпретації.

Загальний характер правової норми, а отже, неможливість указати в ній абсолютно всі конкретні життєві ситуації, є об'єктивною причиною тлумачення. Відповідно до закону загальної ентропії будь-яка передача інформації пов'язана із втратою її певної частини, тому інформація кодується з певним запасом - її носій є більш об'ємним, ніж обсяг переданої інформації. Законодавець же, навпаки, враховуючи потреби практики, повинен створити максимально стислий нормативний текст, що у свою чергу викликає необхідність у роз'ясненні, «розшифровці».

Також тлумачення майже завжди потребують норми з оцінними поняттями: «істотне значення», «істотно зменшений розмір», «істотні недоліки», «негайно», «належним чином», «неналежне виконання», «своєчасно», «малозначність», «Тяжка шкода», «значна суспільно корисна мета».

Враховуючи зазначене, можемо стверджувати, що тлумачення - доволі складний процес, результатом якого може бути правильне розуміння правової норми, але також і помилкове, що викривляє її зміст та породжує помилки.

Дана тема набуває ще більш важливого характеру у зв'язку з діяльністю державних органів і посадових осіб по застосуванню норм права до конкретних життєвих відносин. Прикладом може слугувати неоднорідність сучасної правозастосовної практики, передусім судової. Причиною такої ситуації часто вказують недосконалість чинного законодавства, пробіли і суперечності. Але більш глибокий аналіз цієї проблематики свідчить про наявність істотних проблем саме в тлумаченні закону. У свою чергу виникають питання до правозастосовувачів, що втратили за останне сторіччя «почуття права», що зрештою і призвело до «механізації» судової практики, домінування буквального тлумачення над усіма іншими видами тлумачення. Така ситуація не може бути визнана задовільною, і тому необхідним є дослідження всіх способів і методів тлумачення, які можуть бути використані в практиці для приведення її до певної однаковості, що зумовлює актуальність даного дослідження [1, с. 92].

Проблеми тлумачення становили певний iнтерес для вчених в усі періоди розвитку правової доктрини. Першою масштабною і завершеною роботою в цій сфері на наших теренах по праву вважається монографія Є.В. Васьковського. Серед радянських учених, що займалися даною проблематикою, можна відмітити таких: Ю.Г. Ткаченко, А.С. Шляпочников, Н.Н. Вопленко, А.С. Пиголкин, А.Ф. Черданцев, Н.Л. Гранат. В останні десятиліття долучилися до розроблення проблем інтерпретаційної діяльності такі українські правознавці, як П.М. Рабінович, В.В. Гончаров, В.Я. Карабань, В.Г. Ротань, І.Л. Самсін, Ю.Л. Власов, І.П. Косцова. Разом із тим залишаються питання у вченні про тлумачення, які дотепер не знайшли свого остаточного вирішення.

Одним із таких є способи тлумачення права, важливість яких важко переоцінити, оскільки вони дають нам уявлення про механізм і інструментарій правоінтерпретаційної діяльності. Саме тому метою цієї роботи є дослідження вказаних питань.

Під способом тлумачення в правовій літературі розуміють систему прийомів, засобів та правил здійснення з'ясування змісту та смислу правової норми в результаті їх застосування в інтелектуально-вольовій діяльності суб'єктів права, забезпечують всебічність та комплексність здійснення тлумачення норм права, визначають офіційний або неофіційний характер тлумачення правових норм, зумовлені змістом правової норми та професійним рівнем суб'єктів тлумачення норми права; забезпечують результативність тлумачення правових норм в цілому, а їх застосування відображається в змісті акту тлумачення норм права, що має індивідуально визначений характер [2, с. 64].

Джерелом формування принципів, прийомів і правил тлумачення, використовуваних у національному праві, були загальні правила, більшість 3 яких застосовувалися ще в Стародавньому Римі [3, с. 23]. Серед таких правил, наприклад, правило 
розумної норми, яке передбачає, що право продиктовано розумом, а результат тлумачення не повинний бути безглуздим і даремним, оскільки сам закон не говорить про це.

Варто відмітити, що серед учених дотепер не вироблено єдиного, усталеного підходу до визначення конкретних прийомів і правил з'ясування змісту норм права та їх об’єднання в способи тлумачення.

На думку Є.В. Васьковського, найбільш детальна класифікація способів тлумачення належить Е.М. Форстеру, який, окрім граматичного, розрізняв також цілий ряд способів у залежності від того, які знання застосовуються в процесі тлумачення. Автор виділяв такі способи і, відповідно, види тлумачення, як діалектичне, риторичне, історичне, етико-політичне, поетичне, арифметичне, геометричне, фізико-медичне тощо [4, с. 95-96]. Сам Е.В. Васьковський окремі способи тлумачення (інструментальний підхід) пов'язував з метою. Вченим були сформульовані такі правила тлумачення: кому заборонена ціль, тому заборонена і дія, яка веде до цієї мети; кому заборонені дії, тому заборонена і ціль, до якої вони ведуть, якщо iї не можна досягти іншими діями; хто правомірний до мети, той правомочний і до дії, яка веде до цієї мети, якщо вона не може бути досягнута іншими діями; хто правомірний до відомого дії, той правомочний і до мети, яка досягається цією дією.

Аналіз наукових джерел показує, що вчені правознавці основними способами тлумачення права вважають такі: філологічний (мовний, граматичний), систематичний, логічний, історичний, історико-політичний, спеціально-юридичний, функціональний, телеологічний способи тлумачення [5, с. $28 ; 6$, с. $35-117 ; 7$, с. 131$]$. Разом із тим більшість дослідників саме перші чотири визнають як основні, тому приділимо їм більшу увагу в межах даної роботи.

Граматичний спосіб (мовний, словесний, філологічний, буквальний, лексичний - варіанти назви) [8, с. 133] найбільш розповсюджений. Граматичне тлумачення полягає як у з'ясуванні сенсу використаних у нормах права слів, термінів, так і у встановленні між ними синтаксичного зв'язку. Останній включає в себе дослідження поєднання слів у речення, звороти і т.п. Сюди ж відносять і врахування правил пунктуації. Граматичне тлумачення дає можливість у кожному конкретному випадку з'ясувати зміст слів і термінів, а також сенс речення (речень), з яких складається той чи інший текст закону.

Неможливо здійснити граматичне тлумачення, минаючи лексичний рівень мови. Однією 3 основних проблем лексичного компонента граматичного аналізу є розпізнавання значення багатозначних слів, а також установлення тотожності визначень різних слів і словосполучень, які ви- користовуються під час формулювання правових норм [9, с. 154-155].

Як приклад граматичного тлумачення можна привести норму ч. 2 ст. 36 ЦКУ, згідно з якою суд може обмежити цивільну дієздатність фізичної особи, якщо вона зловживає спиртними напоями, наркотичними засобами, токсичними речовинами, азартними іграми тощо і тим ставить себе чи свою сім'ю, а також інших осіб, яких вона за законом зобов'язана утримувати, у скрутне матеріальне становище. Оскільки законодавець у цій нормі використовує під час перерахування випадки «кому», то для обмеження дієздатності досить одного з трьох перерахованих випадків.

Також як приклад мовного способу тлумачення може виступати й офіційне тлумачення поняття «щомісячне довічне грошове утримання», що міститься у підпункті «е» пп. 165.1.1 п. 165.1 ст. 165 Податкового кодексу України, яке визначене Конституційним Судом України за поданням Верховного Суду України як «неоподаткована грошова виплата як судді, який, маючи право на відставку, продовжує працювати на посаді судді та одержує їі з Державного бюджету України у вигляді щомісячного грошового утримання, що є складовою правового статусу судді і однією з гарантій його незалежності, так і судді у відставці, який одержує таку виплату з Пенсійного фонду України за рахунок коштів Державного бюджету України» [10. с. 16].

Логічне тлумачення - це тлумачення правового акта за його змістом з використанням законів логіки. Саме за допомогою зазначеного способу встановлюється весь обсяг змісту норми, усуваються наявні в ній неясності. Якщо в разі граматичного тлумачення стоїть завдання 3'ясувати буквальний сенс того, що закріплено безпосередньо в тексті, то логічне має на меті за допомогою правил формальної логіки виявити те, що законодавець хотів виразити в тексті закону, але не висловив. За допомогою логічних операцій, які включають аналіз і синтез, побудову силогізму (логічного умовиводу, який складається 3 двох посилок і висновку), 3 нормативних приписів, “розкиданих» по тексту законодавчого акту, формулюється норма права, яка підлягає тлумаченню [11, с. 407].

Логічний спосіб тлумачення полягає у використанні законів і правил формальної та діалектичної логіки під час пізнання змісту правової норми на базі самої норми без звернення до інших способів тлумачення. Логічні закони, принципи та категорії використовуються самостійно, поряд із засобами лінгвістичного аналізу тексту закону $[12$, c. 3$]$.

Конкретні логічні прийоми (висновки з норм, проста дедукція, висновки a fortiori (умовиводи ступеня), висновки з понять, висновки за аналогією, висновки від протилежного, доведення до 
абсурду) і багаточисельні приклади їх застосування можемо знайти в юридичній літературі. Зокрема, використання прийому висновку ступеню застосовується щодо тлумачення ч. 1 ст. 231 Господарського Кодексу («законом щодо окремих видів зобов'язань може бути визначений розмір штрафних санкцій, зміна якого за погодженням сторін не допускається»). Постало запитання про те, чи можна в господарському договорі встановити умову, якою б виключалось застосування штрафних санкцій, встановлених законом стосовно даного виду зобов'язань. Автор зазначає, що якщо тлумачити суто формально, то дійдемо висновку про можливість включення в текст договору такої умови. Але якщо застосовувати логічне тлумачення, то зробимо висновок: якщо забороняється змінювати в господарському договорі розмір штрафних санкцій, встановлених законом, то тим більше забороняється встановлювати в господарському договорі умови, що виключають застосування штрафних санкцій, встановлених законом щодо даного виду зобов'язань. Разом із тим така умова в разі включення в договір не є нікчемною, а оспорюваною [13].

Як ще один приклад логічного способу тлумачення можна привести тлумачення норми ст. 1166 ЦК, яка встановлює, що майнова шкода, завдана неправомірними рішеннями, діями чи бездіяльністю особистим немайновим правам фізичної або юридичної особи, а також шкода, завдана майну фізичної або юридичної особи, відшкодовується в повному обсязі особою, яка її завдала. При цьому виникає питання: під особою, що заподіяла шкоду, розуміти тільки фізичні особи, юридичні особи або ж й інші суб'єкти цивільного права? Якщо звернутися до ст. 2 ЦК, учасниками цивільних відносин є фізичні особи та юридичні особи, а також держава Україна, Автономна Республіка Крим, територіальні громади, іноземні держави та інші суб'єкти публічного права. Це також можна обгрунтовувати тим, що в розділі 2 ЦК три підрозділи носять аналогічну назву. За цією ж підставою можна тлумачити і норми ст. 1190 ЦК, яка встановлює, що особи, спільними діями або бездіяльністю яких було завдано шкоди, несуть солідарну відповідальність перед потерпілим. Ця стаття застосовується не лише до юридичних осіб, але й до будь-яких інших суб'єктів цивільного права.

Під системним способом тлумачення розуміють сукупність прийомів, використання яких, спираючись на зіставлення двох або більше юридичних норм, дозволяє з'ясувати сенс норми права, яка підлягає тлумаченню [14, с. 37].

Як вірно зазначає І.П. Косцова, основними причинами системного тлумачення $є$ системність права, відсилання до інших норм і смислові зв'язки з іншими нормами. Оскільки норми права регулюють суспільні відносини у певній сукупності, між ними існують певні зв'язки, які випливають 3 їх спеціалізації, а зміст конкретної норми права часто залежить від інших норм. Останні у свою чергу можуть розширювати чи звужувати зміст тлумаченої норми права [15, с. 171]. Використання даного способу тлумачення характеризується застосуванням таких прийомів: установлення місця норми права в системі права, встановлення інших норм, які співвідносяться з нормою, що підлягає тлумаченню, на підставі різних взаємозв'язків і залежностей, встановлення ієрархічного становища двох або більше юридичних приписів, залежно від їх приналежності до вищестоящих чи нижчестоящих юридичних актів; зіставлення норм вже після того, як визначено їх підпорядкування, виявлено їхні відносини до близьких за змістом правових інститутів, встановлення особливостей спільного застосування двох і більше правових норм [14, с. 58-62].

Системне тлумачення базується на презумпції логічної єдності закону, а наявні пробіли та протиріччя трактуються як відхід від загального правила. «Передумовою систематичного тлумачення є презумпція відсутності прогалин позитивного права і пов'язана з нею віра в безмежну «логічну розтяжність» понять закону [16, с. 84$]$.

Завдяки системному способу можна виявити юридичну силу правової норми, сферу іï̈ дії. Найчастіше сам текст нормативного акта містить підстави для системного тлумачення. До нього, зокрема, доводиться вдаватися в разі реалізації бланкетних і відсильних норм.

Так, тлумачимо ч. 2 ст. 296 КК України. У даній статті йдеться про «ті самі дії, вчинені групою осіб». Які ж це «ті самі дії»? Звертаючись до ч. 1 цієї ж статті КК України, знайдемо вказівку на хуліганство, тобто грубе порушення громадського порядку з мотивів явної неповаги до суспільства, що супроводжується особливою зухвалістю чи винятковим цинізмом. 3 метою відокремити хуліганство, яке карається в кримінальному порядку, від дрібного хуліганства, яке карається в адміністративному порядку, слід зіставити ст. $296 \mathrm{KK}$ України і Постанову Пленуму Верховного Суду України «Про посилення відповідальності за хуліганство», яка визначає дії, що складають дрібне хуліганство. Щоб з'ясувати зміст ст. 296 КК України стосовно суб'єкта хуліганства, необхідно звернутись до ст. 22 КК України. Там зазначено, що суб'єктом хуліганства є особа, яка досягла 14 -ти років [15, с. 84].

Також можемо навести один із випадків системного тлумачення положень законів органом конституційної юрисдикції України. Зокрема, розглядаючи справу щодо офіційного тлумачення положень статей 38, 78 Конституції України, статей $1,10,12$, ч. 2 ст. 49 Закону України «Про місцеве самоврядування в Україні», Конституційний суд у рішенні від 06 липня 1999 року № 7-рп/99 
(справа про сумісництво посад народного депутата України і міського голови) аргументував свою позицію, виходячи із системних зв'язків правових норм: генетичних, структурних, координаційних, функціональних, семантичних та дійшов висновку, що «сільський, селищний, міський голова є головною посадовою особою громади із представницьким мандатом». Отже суміщення посад суперечить Конституції України [17, с. 46].

Дослідження волі законодавця, правової системи і норм у розрізі їх генетичного розвитку має важливе значення для з'ясування дійсного змісту норми права і зумовлює існування історичного способу тлумачення [18, с. 81$]$.

3 метою правильного розкриття змісту норми доцільно ознайомитися з історією виникнення законодавчого акту. Для цього підлягають аналізу тексти нормативно-правових актів, що втратили силу, але регулювали схожі відносини, матеріали підготовки та прийняття актів. Це дозволяє порівняти діючі та скасовані норми, визначити мету, обставини, причини, які зумовили прийняття певного припису. Наприклад, у ст. 421 ЦК РРФСР 1922 р. вживається термін «предмет розкоші». Зміст цього терміна зазнав серйозних змін у силу збільшення матеріального добробуту людей і тому тепер він тлумачиться трохи інакше, чим у двадцяті роки, коли був прийнятий Цивільний кодекс.

Не можемо не розглянути у світлі тенденції переосмислення підходів до юридичного тлумачення такий спосіб, як телеологічний, що передбачає з'ясування смислу норми права за допомогою їі мети. Підтримуючи думку Г. Мальцева про те, що «телеологічний аналіз юридичної норми відкриває шлях у світ правових цінностей, ідеалів, ідеології взагалі», Б.В. Малишев підкреслює, що «телеологічний спосіб тлумачення є основним напрямом пізнання цінностей, що закладені в нормативну структуру права». Він зазначає: «найважливішим наслідком використання цього способу тлумачення є те, що він запобігає формалізованому, «бюрократичному» тлумаченню норм права, який спотворює аксіологічні установки правового регулювання, зневажає соціальні наслідки того чи іншого висновку про смисл норми права; цей спосіб допомагає впроваджувати у поведінку суб'єктів стандарти основоположних принципів права, забезпечуючи тим самим доцільність кожної норми права» [19, с. 8, 13]. При цьому кожен спосіб складається з певного набору правил тлумачення.

В юридичній літературі можемо зустріти такий підхід, коли науковці з практичною метою задля «спрощення» розуміння процесу юридичного тлумачення таким чином викладають перелік основних (найважливіших) правил інтерпретаційної діяльності:

- «золоте правило» (термінам й іншим словами тексту законодавчого акта надається значення, яке вони мають у літературній мові, якщо немає підстав надання їм іншого значення);

- науковим, технічним та іншим спеціальним термінам, які вживаються в тексті законодавчого акту, надається те значення, яке вони мають у відповідній галузі знань, якщо в законі не встановлено інший зміст конкретного терміна;

- за наявності автентичного (тобто наданого законодавцем) або легального (тобто наданого офіційним уповноваженим органом) роз'яснення терміна, що використовується в тексті закону, інтерпретатор повинен дотримуватися цих роз'яснень;

- за неоднозначності правового тексту під час тлумачення повинна віддаватися перевага найбільш справедливому, з огляду на конкретну правову систему і соціальні відносин, варіанту змісту;

- під час тлумачення необхідно враховувати конституційні принципи, міжнародні договори, практику вищих судових органів держави, а також загальновизнані доктринальні погляди фахівців у даній галузі права;

- в окремих випадках під час тлумачення має бути встановлено, якими цілями керувався законодавець, створюючи норму права, що інтерпретується [20].

Разом із тим постає питання: як саме використовувати ці методи для тлумачення нормативних приписів? Якому віддати перевагу, чи потрібно застосовувати їх усі одразу? Більшість дослідників права притримується думки, висловленої в роботі А.В. Смірнова та А.Г. Манукян «Тлумачення норм права», які стверджують, що саме граматичний спосіб насамперед підлягає застосуванню під час тлумачення норми права [21, с. 25]. Якщо визначати принципи взаємодії граматичного та системного тлумачення норм права, то можна зазначити таке: пріоритетність перед іншими граматичного способу зовсім не означає його самодостатності. Воно за визначенням обмежене рамками тієї словесної оболонки, в яку оформлений конкретний правовий припис. За межі окремо взятої синтаксично закінченої думки інтерпретатор, який використовує лише граматичний спосіб, не те, що не буде, але й не зможе вийти. Така інструментальна обмеженість граматичного тлумачення якраз і повинна бути подолана за допомогою інших способів тлумачення, передусім системного, що дозволяє вийти на наднормативний рівень. Отже, «системний» сенс норми права є первісним по відношенню до «граматичного» [22, с. 25].

В.Л. Горбатюк таким чином пропонує своє бачення використання досліджуваних методів задля досягнення мети тлумачення: «граматичне тлумачення - телеологічне тлумачення - з'ясування відповідності сутності змісту правової норми принципам права - системне тлумачення - спеціально-юридичне тлумачення - логічне тлумачення - 
функціональне тлумачення - історичне тлумачення - повторне застосування процедури тлумачення в разі отримання нових даних [23, с. 83].

Варто відмітити: що стосується тлумачення індивідуальних актів у праві, зокрема договорів, то до них можемо застосовувати вищезазначені способи з урахуванням того, що в разі використання системного тлумачення буде враховуватися текст інших розділів договору, окрім норм законодавства, а в разі використання історичного - документи сторін, що передували його укладанню.

На підтвердження вважаємо за необхідне навести підхід до використання способів тлумачення індивідуально-правових договорів, викладений у роботі 0.О. Березіної: оскільки договір у більшості випадків здійснюється в письмовій формі, тому неминуче граматичне тлумачення; воля сторін договору виражається і в логічній організації, отже, необхідно логічне тлумачення; укладаючи договір, сторони переслідують певні цілі, а отже, ïх 3'ясування здійснюється через телеологічне тлумачення; договір здійснюється у визначених умовах, отже, потрібне знання специфіки відносин, чинників та умов реалізації даного договору - функціональне тлумачення; якщо кожне положення договору пов'язане з іншими умовами і зі змістом договору в цілому, нормами законодавства, то треба вдаватися до систематичного тлумачення; спеціально-юридичний спосіб тлумачення договору є необхідним, оскільки в ньому наявні спеціальні дефініції, презумпції, юридичні конструкції; договір створюється і реалізується в певній історико-політичній обстановці, тому потрібно історико-політичне тлумачення; оскільки договір має динаміку зародження і розвитку (попередні листування, переговори, укладення, виконання, внесення змін), тобто свій генезис, виникає потреба і в генетичному тлумаченні та ін. [24, с. 135-136].

Також таким, що має велике значення для практичної діяльності, є дослідження Н.В Степанюк щодо правил тлумачення цивільно-правових договорів, яке здійснено автором на підставі вивчення законодавства інших країн та міжнародних договорів. Наведемо лише окремі такі правила, викладені автором:

- прийняти той зміст, який буде мати юридичні наслідки, а не використовувати вислови в тому сенсі, який не має ніяких наслідків;

- значення неоднозначних висловів повинно бути встановлено з контексту всього договору в цілому;

- усі умови повинні тлумачитися у взаємозв'язку;

- під час тлумачення договору повинні враховуватися звичаї місця укладення договору, а недостатня воля сторони повинна заповнюватися звичайними умовами.
- у разі сумніву договори повинні тлумачитися проти того, хто висловив умову, і на користь того, хто прийняв на себе зобов'язання.

При цьому автор наголошує, що проблемами розробки таких правил тлумачення повинні займатися судова практика і доктрина. Наприклад, у праві Англії правила тлумачення договорів повністю вироблені судовою практикою, де категорія розумної особи дуже часто використовується під час тлумачення договору. Якщо в континентальній системі права необхідно виявлення справжньої волі сторін, то правила тлумачення, вироблені англійськими й американськими судами, передбачають займати позицію звичайного розуміння і розумного значення [25, с. 170-194].

Є. Звєрєв у роботі «Тлумачення міжнародних договорів національними судами: європейський досвід та українська практика» запропонував комплексну методику тлумачення міжнародних договорів національними судами України з поділом його на відповідні етапи: з' ясування їх природи і статусу в міжнародному праві та в національному праві [26, с. 185].

Висновки. Отже, відповідні компетентні органи, які здійснюють правозастосовну діяльність, не вправі відмовити у вирішенні спору через незрозумілість правової норми, що підлягає застосуванню. 3 метою уникнення неправильного застосування необхідно передусім установити зміст норми, для чого використовувати всі відомі способи, прийоми, правила тлумачення до повного з'ясування дійсного змісту норми. Немає чітко визначених правил використання зазначених способів. Вони можуть використовуватися суб'єктом тлумачення всі одночасно, або може бути обраний один чи кілька на розсуд особи, залежно від можливості досягнення мети тлумачення. При цьому якщо граматичне i логічне тлумачення відштовхуються від самих текстів, то системний та історичний способи спираються на елементи зовнішні.

Відмова правозастосовувача від використання всього арсеналу призводить до однобокості в застосуванні норм закону. Тлумачення грунтується на тезі, що система норм права повинна бути вільною від протиріч, і кожна норма повинна гармоніювати з усією системою. Тому в межах даної тези потрібно вибрати той варіант тлумачення, за якого правова норма буде найкраще гармоніювати з іншими нормами.

\section{Jimepamypa}

1. Личман Л. Толкование норм гражданського законодательства: теория и практика. Legea Si Viata, 2014. August. C. 92-95.

2. Котенко М.В. Спосіб тлумачення правових норм як юридична категорія. Науковий вісник Ужгородського національного університету, Серія Право. 2013. Випуск 21. Частина II. Том 1. С. 62-64. 
3. Перетерский И.С. Толкование международных договоров. Москва : Госюриздат, 1959. 172 с.

4. Васьковский Е.В. Цивилистическая методология. Москва : Центр ЮрИнфоР, 2002. Ч. 1. Учение о толковании и применении гражданских законов. 508 с.

5. Вопленко Н.Н. Толкование права. Волгоград : Изд-во Волгоградского госуниверситета, 2007. 126 с.

6. Черданцев А.Ф. Толкование советского права. Москва, 1979. 168 с.

7. Алексеев С.С. Право: азбука - теория - философия. Опыт комплексного исследования. Москва : Устав, 1999. $712 \mathrm{c.}$

8. Тодика Ю.М. Тлумачення законів і Конституції України: теорія і практика : монографія. Харків : Факт, 2001. 328 c.

9. Волосюк Е.А. Грамматическое толкование уголовного закона и его компоненты. Общество и право. 2012. № 3 (40). С. 154-157.

10. Баїк O.I. До питання тлумачення податково-правових норм. Международный научный журнал "Интернаука». Серия: «Юридические науки». 2018. № 2 (7). С. 13-20.

11. Скакун О.Ф. Теорія держави і права : підручник. ; пер. з рос. Харків : Консум, 2006. 688 с.

12. Чулінда Л.Г. Застосування юридико-лінгвістичного та логічного способів тлумачення нормативно-правових актів. Законодавство України. 2005. № 2. C. $3-8$.

13. Новітнє вчення про тлумачення правових актів : навч. посіб. з курсу тлумачення прав. актів для суддів, що проходять підвищення кваліфікації, і кандидатів на посади суддів, що проходять спеціальну підготовку / В.Г. Ротань та ін. ; за ред.: В.Г. Ротань. Харків : Право, 2013. 751 с. URL: https://pravo-izdat. com.ua/image/data/Files/132/1-30.pdf (дата звернення: 16.11 .2019$)$

14. Толстик В.А., Дворников Н.Л., Каргин К.В. Системное толкование норм права. Москва : ИД «Юриспруденция», 2010. $136 \mathrm{c.}$

15. Косцова І.П. Системне тлумачення норм права : дис. ... канд. юрид. наук : 12.00.01 ; Івано-Франківський університет права імені Короля Данила Галицького. Івано-Франківськ, 2016. 218 с.

16. Люблинский П.И. Техника, толкование и казуистика уголовного кодекса: Пособие к практическим занятиям по уголовному праву. Петроград : Типо-лит. Руманова, 1917. 270 с.

17. Євграфова Є. Доктринальне тлумачення норм права (законів): природа і здійснення. Вісник Акаделії правових наук України. 2010. № 2. С. 40-51.

18. Власов Ю.Л. Проблеми тлумачення норм права : монографія. Київ : Ін-т держави і права ім. В.М. Корецького НАН України, 2001. 180 с.

19. Малишев Б.В. Телеологічний спосіб тлумачення норм права: загальнотеоретичні аспекти. Адвокат. 2011. № 10 (133). С. 7-14.

20. Долголенко Т.Н. Цели и правила толкования норм права. Вопросы современной юриспрудениии : сб. ст. по матер. $\mathrm{X}$ междунар. науч.-практ. конф. Новосибирск : СибАК, 2012. URL: https://sibac.info/conf/ law/x/26772 (дата звернення: 02.12.2019).

21. Смирнов А.В., Манукян А.Г. Толкование норм права : учебно-практ. пособие. Москва : Проспект, 2008. 144 c.

22. Васев И.Н. Грамматический и системный способы толкования норм права: характер взаимодействия. Юрислингвистика. 2018. № 7-8. С. 17-26.

23. Горбатюк В.Л. Багатоаспектна процедура тлумачення правових норм. «Інфорлація $і$ право». 2016. № 1 (16). C. $79-84$.
24. Березина Е.А. Толкование договора как вид юридического толкования : дисс. ... канд. юрид. наук : 12.00 .03 ; Уральская государственная юридическая академия. Екатеринбург, 2001. 226 с.

25. Степанюк Н.В. Толкование гражданско-правового договора : дисс. ... канд. юрид. наук : 12.00 .03 ; Московская государственная юридическая академия. Москва, 2008. 213 с.

26. Звєрєв Є.О. Тлумачення міжнародних договорів національними судами: європейський досвід та українська практика : дис. ... канд. юрид. наук : 12.00.01 ; Національний університет «Києво-Могилянська академія». Київ, 2015. 227 с.

\section{Анотація}

Антошкіна B. $\boldsymbol{K}$. Способи і правила тлумачення норм права та договорів. - Стаття.

Ця стаття присвячена такому аспекту права інтерпретаційної діяльності, як методи тлумачення. Загальний характер правової норми, а отже, неможливість указати в ній абсолютно всі конкретні життєві ситуації є об'єктивною причиною тлумачення. Питання про те, як тлумачити право, є важливим у теорії юридичного тлумачення. Воно дає нам уявлення про механізм та інструменти такої діяльності. Під методом тлумачення в юридичній літературі розуміють конкретні прийоми та знання правил, необхідних для уточнення реального змісту правових норм. Слід зазначити, що серед учених досі не вироблений єдиний підхід до визначення конкретних методів і правил, що роз'яснюють закон, ïx об’єднання в способах тлумачення.

Автор статті розглядає граматичний, логічний, системний, історичний способи тлумачення та їх застосування у праві. Граматичний спосіб (словесний, філологічний, буквальний, лексичний - варіанти назви) $€$ найпоширенішим. Логічне тлумачення - тлумачення правового акта з використанням законів логіки. Існування системного методу визначено системністю права.

У статті розглядаються питання застосування вказаних способів тлумачення для з'ясування змісту договорів.

Автором наголошується, що відповідні компетентні органи, які здійснюють правозастосовну діяльність, не вправі відмовити у вирішенні спору через незрозумілість правової норми, що підлягає застосуванню. 3 метою уникнення неправильного застосування необхідно насамперед встановити зміст норми, для чого використовувати всі відомі способи, прийоми, правила тлумачення до повного з'ясування дійсного змісту норми. Немає чітко визначених правил використання зазначених способів. Вони можуть використовуватися суб'єктом тлумачення всі одночасно, або може бути обраний один чи кілька на розсуд особи, залежно від можливості досягнення мети тлумачення. При цьому якщо граматичне і логічне тлумачення відштовхуються від самих текстів, то системний та історичний способи спираються на елементи зовнішні.

Відмова правозастосовувача від використання всього арсеналу призводить до однобокості в застосуванні норм закону. Тлумачення Ірунтується на тезі, що система норм права повинна бути вільною від протиріч і кожна норма повинна гармоніювати з усією системою. Тому в межах даної тези потрібно вибрати той варіант тлумачення, за якого правова норма буде найкраще гармоніювати з іншими нормами.

Ключові слова: тлумачення правових норм, спосіб тлумачення правових норм, правила тлумачення, співвідношення способів тлумачення правових норм. 


\section{Summary}

Antoshkina $V . K$. Methods and rules for interpreting of law and contracts. - Article.

This article is devoted to problems of interpretation in law, including methods of interpretation. The general nature of rules, inability to specify it absolutely all specific life situation is an objective reason for interpretation. The question of how to interpret law is important in the doctrine of interpretation. They give us an idea of the mechanism and tools for such activities. Under the method of interpretation in legal literature understand specific techniques and knowledge of the rules necessary to clarify the interpretation of the subject real content of legal norms. It should be noted that among the scientists are still not developed a common approach to determining the specific methods and rules clarify the law, their union in ways of interpretation.

The author of the article considers the grammatical, logical, systematic, historical interpretation and their application in law. The grammatical way (verbal, philology, literal, the lexical - variants of the name) the most common. The logical interpretation - an interpretation of a legal act on its contents using the laws of logic. The existence of systemic predetermined systematic interpretation of law.
Interpretation of the individual acts in law, including contracts made by the same means. When using systematic interpretation be accounted into other parts of the contract, with the provisions of the law, and the use of historical - documents the parties prior to its conclusion.

Consequently the competent authorities that carry out law enforcement activities is not entitled to refuse the dispute through obscurity legal standard. There are no clearly defined rules of these methods.

They can be used all at once or can be selected for one or more individual discretion, depending on the possibility of achieving the objective interpretation. Thus if the grammatical and logical interpretation repelled from the texts themselves, the systematic and historical methods rely on elements external to them.

Disclaimer enforcer of the whole gamut resulting in a one-sided application of the law. The interpretation is based on the premise that the system of law should be free from contradictions and each provision should be in harmony with the whole system.

Key words: interpretation of law, method of interpretation of law, rules of interpretation, correlation of ways of interpretation of legal norms. 